ISLAMIC BANKING: Jurnal Pemikiran dan Pengembangan Perbankan Syariah, Volume 7 Nomor 2 EdisiFebruari 2022

\title{
THE MARKETING ETHICS OF ISLAMIC BANKS: A THEORETICAL STUDY
}

\author{
Havis Aravik \\ Perbankan Syariah, STEBIS IGM Palembang \\ Email: havis@ stebisigm.ac.id \\ Hoirul Amri \\ Program Studi Ekonomi Syariah, Universitas Muhammadiyah Palembang \\ Email: amri@ump.ac.id \\ Rahma Febrianti \\ Genius Learning Center, Palembang \\ Email: febrianti.rahma16@gmail.com
}

\begin{abstract}
Ethics is a crucial component in human interaction, including in the field of marketing in Islamic banks. This article discusses the marketing ethics of Islamic banks: a theoretical study. The aim is to know the marketing ethics of Islamic banks comprehensively. The type of research used in this article is qualitative, which bases on library data focusing on text study and literature review. The results of this study show that there are several marketing ethics of Islamic banks such as promoting using gentle words, marketing is done with courtesy; being professional, fair, and transparent, placing customers as equal partners, do not consider competitors as enemies and working with a culture that following the Sunnah of the Prophet Muhammad.
\end{abstract}

Keywords: Ethics, Marketing, Islamic Banking

\begin{abstract}
Abstrak
Etika merupakan komponen penting dalam interaksi manusia, termasuk pada bidang pemasaran yang ada pada bank syariah. Artikel ini membahas tentang etika pemasaran bank syariah; sebuah kajian teori. Dengan tujuan untuk mengetahui secara komprehensif etika pemasaran bank syariah. Artikel ini menggunakan jenis penelitian kualitatif yang berbasia pada data kepustakaan dalam arti bertumpu pada kajian dan telaah teks. Hasil penelitian ini memperlihatkan bahwa terdapat beberapa etika pemasaran bank syariah seperti promosi mengunakan kata-kata yang lembut. Pemasaran dilaksanakan secara sopan santun, bersikap professional dan adil, transparan, meletakkan nasabah sejajar sebagai mitra, dan pesaing bukan musuh serta budaya kerja mengikuti sunnah Rasulullah SAW.
\end{abstract}

Kata Kunci; Etika, Pamasaran, Bank Syariah 


\section{Introduction}

The company's progress is inseparable from the human resources' role that has high competence have high competence, supported by good ethics in each individual. Ethics has a critical role in the business field when organizations think that profit is no longer the only goal. It is imperative that a business/organization in carrying out its business processes also prioritizes good ethics so that the company will continue to have a good image and quality in the minds of consumers. The role of ethics strongly supports the progress and development of the company because ethics are norms and values for the common good. Therefore, every individual must keep good ethics in behavior, as well as organizations/companies, uphold ethics so that it will create a conducive and prosperous business environment. Ethics act as signs in a community group that can guide and remind its members to a commendable action (good conduct) that must be obeyed and carried out (Musoli, 2017). It says that ethics is the science of moral norms that determine how humans should live in society to behave. It relates to the rules or principles that will determine the pattern of good or bad behavior in life activities.

Terminologically, the Qur'an interprets ethics with the word al-Khuluq, which is the meaning used to describe the words Khair, bir, qist, 'adl, haqq, and taqwa. In terms of language, al-Khuluq means behavior, temperament, or character. Meanwhile, in terms of terminology, al-khuluq is defined as a behavior, but they must do it repeatedly. It is not enough to do a good deed once or only occasionally. A person has morals if it can be arisen automatically, driven by motivation from within, and carried out without much thought and repeated considerations so that it is impressed as a compulsion to act (Iswandi, 2014).

Islam is a way of life that teaches human beings about their relationship with God, the universe, and the relationship between their ethics and the economy and political system. It is a source of values and ethics in various aspects of human life, including the marketing field. Islam has a comprehensive and integral insight into marketing ethics that is the source from the Qur'an and Sunnah as a reference in all aspects of life and business (Al-Nashmi \& Almamary, 2017). Islam provides instructions that marketing 
ISLAMIC BANKING: Jurnal Pemikiran dan Pengembangan Perbankan Syariah, Volume 7 Nomor 2 EdisiFebruari 2022

activities must create a harmonious relationship, mutual pleasure, and no elements of exploitation and fraud.

People expect their business will progress and develop rapidly by using and complying with marketing ethics because it always gets blessings from Allah SWT in this world and the hereafter (Dawwah, 2008). However, ethically, a marketer must show a sense of responsibility to; Allah SWT, society, self-welfare, and the environment (Basrowi \& Ronaldo, 2019). So it is very reprehensible if there are marketers who exploit customers or commit fraud and dishonesty. All of these are not part of the Islamic vision in which it highly upholds brotherhood, equality, and humanity (Zarrad \& Debabi, 2015).

The need for ethics in the marketing field also applies to Islamic banking. As a bank that carries Islamic values, of course, Islamic banks need ethics in the field of marketing, so that customers can feel safe, and create maslahah and falah as the pinnacle of Islamic teachings. Including a good and correct understanding of Islamic banking marketing ethics, both in theory and practice will support a positive perception of Islamic banks, which has an impact on public interest in saving to Islamic banks.

\section{Research Methodology}

This type of research is library research that concentrates on the study and analysis of the text. It is because the data sources used are in the form of literature data. Library research is a series of activities related to collecting library data, reading and taking notes, and processing research materials. It is a study that utilizes library resources to obtain research data. This study is qualified as qualitative research. The data collection method in this study uses primary sources obtained from books that discuss Islamic bank marketing ethics. Then secondary sources are obtained from various opinions that support the research. After the data is collected, it will be analyzed using descriptive-qualitative analysis techniques. 


\section{Discussion}

\section{Definition of Islamic Bank Marketing Ethics}

Marketing is one of the activities in the economy that helps in creating economic value. The economic value itself determines the price of goods and services. The essential factors of creating that value are production, marketing, and consumption. Marketing connects production and consumption activities. Marketing has a central role in the company's business map and contributes to product strategy. Marketing is one of the activities done by the company to maintain the company's viability in a competitive business environment and to develop its business. According to the American Marketing Association, marketing is a process of planning and executing the creation, pricing, promotion, and distribution; including, the ideas, products, and services to create exchanges that provide satisfaction to individuals and organizations. The marketing expert, Kotler, even simplified marketing into a marketing mix of product, price, place of sale, and promotion.

Marketing is a business philosophy characterized by the satisfaction of consumer needs as an economic and social condition for the company's viability. The marketing department in a company plays a crucial role in achieving a large sales volume because fulfilling the desired sales volume means that the marketing department's performance in introducing the product has been going well and correctly. People often consider sales and marketing are equals, but they are different principally (Swastha \& Irawan, 2015). In the state of a company, marketing becomes a functional division because decent marketing can arrange sales volume and product position in the market. Four pillars that become the marketing foundation are market targeting, customer needs, integrated marketing, and profitability (Hendarsyah, 2020).

Marketing is reflected as an art rather than science so that the marketing expert relies more on verdict skills in making policy rather than being oriented to a specific science. The economist's view of marketing is creating the time and place where the product is needed or desired and then delivering the product to satisfy the needs and wants of consumers (marketing concept) (Hermawan, 2012).

Marketing is one of the essential aspects in the business world, not least in Islamic banks. The marketing concept of Islamic banks principally is not much different from 
ISLAMIC BANKING: Jurnal Pemikiran dan Pengembangan Perbankan Syariah, Volume 7 Nomor 2 EdisiFebruari 2022

the existing marketing concepts. The marketing concept is a science and art that directs to the creating, delivering, communicating value to consumers, and maintaining relationships with stakeholders (Al-Arif, 2012). Islamic bank marketing ethics are various activities of planning financial service products, determining prices, promoting and distributing products that follow customer needs and demands; Islamic ethical values become the foundation of these activities (Sari, Kosim, and Arif, 2018). Thus, Islamic bank marketing is a strategic business discipline that directs the process of creating, offering, and changing the value from an initiator to sharia bank stakeholders, which in the whole process is under Islamic sharia contracts and principles. The aspect of Allah's supervision of His servants (muraqabatullah) is the main foundation of awareness of every marketer in their marketing activities.

The objective of Islamic bank marketing is, in theory, the same as the goal of marketing in general:

1. Potential consumers are aware of the manufactured items so that the corporation can meet all of their demands for the products manufactured.

2. All marketing operations may be explained in detail by the company. This marketing activity covers a variety of actions ranging from product explanations, product design, product promotion, product advertising, consumer communication, and product delivery so that it reaches consumers as soon as possible.

3. Understanding and knowing customers is somewhat way that the product fits the consumer and can be marketed on its own (Hermawan, 2012).

As a result, Islamic banks must engage in a variety of initiatives of infinite development (un-ending improvement) to become a key player in their market and become the primary reference for consumers, which leads to contentment and even loyalty. As a result, Islamic banks must have an established marketing approach and not just rely on psychological mass to acquire consumers (Aravik \& Hamzani, 2021).

\section{Marketing Values of Islamic Banks}

One of the most significant aspects of Islam is marketing. Marketing is a social process that allows individuals and groups to sell, create, and trade items and services 
freely with the ultimate objective of obtaining the desired demand (Abbas et al., 2019). Marketing is an essential component of commerce. Islam regards trade as a significant resource for a person to earn a living under Islamic conditions. Before his prophetic life, Prophet Muhammad SAW was a prosperous businessman. For a long time, Prophet Muhammad SAW had used marketing in his businesses (Shamsudin et al., 2010). As a result of following the example of the Prophet Muhammad SAW's character, the marketing values of Islamic banks are as follows:

The first is Siddiq. Siddiq means being truthful and the honest spoken word, beliefs, and actions based on Islamic teachings. It corresponds to QS. Aal-e-Imran [3]: 1517, An-Nisa' [4]: 69, Al-Ma'idah [5]: 119 (Al-Arif, 2012). Simply put, honesty means formulating facts and views as they are so that others can believe them. Honesty can be done by others or with yourself. True is a noble character that decorates the morals of those who believe in Allah and the invisible (Syauqi et al., 2019). Honesty and truth are human characteristics for communicating and acting as wisely and honestly as possible. Honesty is closely related to the truth as a sense of value. Honesty also includes listening, thinking, speaking, and other actions performed in complete truth (Antonio, 2013a). Honesty is, among many other honors, the basis of all actions. Honesty is the basis of social discipline and cleanliness for all issues. Therefore, in the state of Islamic banks, marketers should not be arrogant or exaggerate the sold products to pursue sales goals. Since customers and banks are equal partners, their financial planning advice should be based on the principle of mutual trust and aimed at strengthening customers rather than deceiving them. The nature of this Siddiq in work and business reflects sincerity and determination of time, promises, services, reporting, acknowledging the weaknesses and strengths of the product and then improving it, and refraining from all forms of lies and deception, whether to oneself, colleagues, the company, or partners (Al-Arif, 2012).

Second is Fathanah. Fathanah (intelligent): can be understood as intellectual, beauty, or knowledge that every Islamic bank marketer must possess so that every task performed is successful, efficient, and devoid of fraud, and then he must utilize the various potentials that Allah has given him (Rozalinda, 2016). An astute marketer will be able to comprehend, appreciate, and identify his obligations and responsibilities, as 
ISLAMIC BANKING: Jurnal Pemikiran dan Pengembangan Perbankan Syariah, Volume 7 Nomor 2 EdisiFebruari 2022

well as carry them out thoroughly. With this trait, Islamic bank marketers may develop creativity and thus the ability to execute numerous ideas that benefit the organization. Only those who wish to improve their knowledge, either by self-learning or through official education, coaching, and training, might claim to be creative and inventive (AlArif, 2012). Furthermore, knowledgeable and wise Islamic bank marketers will be capable of answering questions about the product as thoroughly as possible, explaining the benefits of their products very comprehensively and carefully throughout comparison to their competitors, and making customers hopeful, impressed, and satisfied with the explanations.

Third, Amanah (trusted, credible): signifies trustworthiness, responsible, and credibility, and thus a willingness to carry out anything in compliance with the expectations. Trustworthy sharia bank marketers indicate that both the institution and clients trust them. Dependable marketers will result in a substantial income for businesses. Aside from the fact that they do their job well, the firm will benefit from the image built by customers of the trustworthiness of the company's marketers. As a result, a consumer will be attracted to a product or business. As a result, the firm will reap significant and long-term benefits and profits. The Prophet Muhammad SAW emphasized that trust is the most valuable capital in the business, and he began his venture with merely trust capital, without physical money. Before receiving the message of apostleship, the Prophet Muhammad SAW already had significant value in him, namely community trust. As a result, even though the Prophet Muhammad only taught Islam for quite a brief time, its teachings have spread extensively (Fauzia, 2014).

Fourth, Tabligh means to convey, to communicate, and to be transparent. Islamic bank marketing must have reliable communication skills while also honest administration of the company and economic resources. Marketing must also be willing to converse product benefits in an appealing and targeted manner while maintaining honesty and truth. Tabligh is the concepts of personal and mass communication, marketing, sales, advertising, mass opinion formation, open management, transparency culture, and all that (Mujahidin, 2014). 
Prophet Muhammad was a great communicator, with elegant phrases and plain language. The words are straightforward, the message is not confusing; they are attractive, engaging, and educational, empowering Allah's Messenger to enlighten intellectually and spiritually rejuvenate his followers. The Prophet SAW's words are exceedingly persuasive (influential) for his people. He was known as Jawami'ul Kalim, a guy whose statements were short yet profound, containing numerous pearls of wisdom. He was fluent in the Arab languages and could communicate with each tribe in their language. He possesses the eloquence of the Bedouin and the purity of pronunciation of those who are already further evolved in civilization, as well as God's assistance via revelation (Antonio, 2013b).

\section{Marketing Ethics in Islamic Banks}

In Islam, marketing ethics is grounded on value maximization, which necessitates empathy for others and reverence for Allah's creations, which entails refraining from damaging actions toward others and preventing the spread of unethical marketing methods. Adherence to Islam's ethical framework, which is built on honesty and fairness, ensures the dignity and freedom of human beings (both consumers and producers), their minds, and their consciences from all forms of enslavement and exploitation for monetary gain. As a result, Islamic banking marketing ethics in principle attempts to guarantee the emergence of harmony and create justice in society, consequently improving dignity and defending human rights. Islamic banks can perform their marketing tasks ethically by employing Islamic marketing principles, ensuring that parties involved in the marketing process, do not become victims of marketing manipulation (Sari, Kosim, and Arif, 2018). According to Islam, marketers should never exploit their clients or engage in dishonesty, fraud, or deceit. Every unethical marketing practice, for example: commits injustice, defies the brotherhood principle, and denies the equality of humanity is not part of Islamic teachings and vision, so every Muslim must reflect Islamic ethics in all aspects of life, including business (Yesil \& ., 2012).

According to Moh Toriquddin (2015), Islamic banks' marketing ethics are as described in the following: first, advertising must utilize gentle language. To promote Islamic banks, a marketer must be pleasant (Surah An-Nahl [16]: 125, Ta Ha [20]: 44). 
ISLAMIC BANKING: Jurnal Pemikiran dan Pengembangan Perbankan Syariah, Volume 7 Nomor 2 EdisiFebruari 2022

In the banking business, the best way to provide the service to consumers is to say hello (greeting warmly), thank you (appreciating), and smile (smiling friendly). In addition, even if you are right, never urge consumers to argue with you.

Second, the marketing is run decently. When doing business with other people, believers are commanded to be generous, polite, and pleasant (Q.S. Al-Hijr [15] 88, Luqman [31]: 18-19). Marketing in banking must perform a courteous attitude since it will make one's soul joyful if the marketer treats them politely. Furthermore, we are prohibited from being arrogant to anybody because haughty individuals will not obtain God's grace. We must communicate well when met by someone less intelligent.

Third, being professional in promotions, such as being fair in advertising (Surah AlAn'am [6]: 152, Al-Isra' [17]: 35), and towards people of other religions (An-Nahl (16): 90, Al-Mumtahanah (60): 8). In terms of promotion, they do not only provide transactional products, but they also serve satisfaction to clients generously and avoid inflict loss transactions.

In the Islamic concept, an equitable marketer of Islamic banks is one who "does not oppress and is not oppressed" (Surah Al-Baqarah [2]: 279-280) (Jusmalani, 2008). Sharia marketers must not discriminate against their consumers, be partial, take sides, or judge someone based on their race, nationality, culture, or position. It is necessary to serve with a smile and humility (khidmah). A marketer's primary attitude is one of service. When interacting with business partners, believers are required to be generous, courteous, and friendly. When a company is sustained by the best service, it will continue to expand and succeed. For example, warmth and a smile to customers will benefit the company (Arifin, 2009).

Fourth, being honest in marketing, including not selling counterfeit items (An-Nisa' [4]: 29), realistic is not exclusive, obsessive, anti-modern, inflexible, and responsible (QS. Al-Hashr [59]: 18). Sharia marketers are professionals who appear clean, modest, humble, and not pompous (Safitri et al., 2016). Regardless of the model or style of apparel he wears, he works in all marketing activities by prioritizing religious principles, piety, moral qualities, and honesty. However, it is a must to underline that being pragmatic does not indicate that in an "emergency" situation, Muslim marketers 
can do something that breaches Islamic law principles (Tabrani \& Marlizar, 2017). Marketers are not commanded to worship anybody other than Allah (Surah Ar-Rad [13]: 36 and Luqman [31]: 32). Prioritizing the interests of the larger society over personal interests and establishing a balanced lifestyle between worldly and eternal issues. Allah SWT said: "But seek, through that which Allah has given you, the home of the Hereafter; and [yet], do not forget your share of the world. And do good as Allah has done good to you. And desire not corruption in the land. Indeed, Allah does not like corrupters". (QS. Al-Qasas [28]: 77).

Allah's Messenger (SAW) said: "It is not the best of you all, that is, the one who leaves the worldly life for the sole purpose of pursuing the Hereafter, nor is it the best person who leaves the Hereafter for the sole intention of pursuing the worldly life, so that both are achieved in a balanced way, because the world is a means to achieve the afterlife, and you should not be a burden to humans," (HR. Ibn Asakir from Anas).

Fifth, consumers or clients are treated equally as partners, rather than as "cash cows" that may be used to continue purchasing their products. Consumers, as partners, do not drive marketers to engage in tactics and transactions that are unfavorable for them. Even marketers are encouraged to create valuable products and ask for customer feedback to establish family values between businesses and individuals. A sharia bank marketer must be capable of fulfilling his function to become a yatafaqqohu fiddin (spreader of knowledge and understanding to consumers) and yunziro qoumahum (directing subordinates to understand and comprehend) (Aravik et al., 2020).

Sixth, the competitor's position is not a party that must be defeated or even eliminated. Competitors are partners in implementing Islamic economics and banking in the field, not adversaries that be avoided or destroyed. A marketer must maintain a friendly and unified demeanor at all times. There is no discrimination, especially among Muslims, regardless of ethnicity, gender, or skin color. The sole difference amongst Muslims is piety.

Seventh, the work culture developed in the marketing of Islamic banks differs from that of traditional organizations. The Prophet SAW's characteristics became the foundation of the work culture, which include shiddiq (honesty), fathanah (competence or intelligence), Amanah (responsibility), and tabligh (ability to disseminate) (Aravik \& 
ISLAMIC BANKING: Jurnal Pemikiran dan Pengembangan Perbankan Syariah, Volume 7 Nomor 2 EdisiFebruari 2022

Hamzani, 2021). The aforementioned ethical values can be applied to the seven controllable elements of a marketing strategy known as the marketing mix. The marketing mix is a description of a set of instruments that management may employ to affect sales (Firdaus, 2005). In addition, the marketing mix is a controllable set of tactical marketing tools that the firm combines to produce the response the target market wants (Shinta, 2011). The seven elements include:

1) The Product

The term product comes from the English phrase "anything created by work or the like." The verb form of the word product, produce, is a Latin absorption that implies to lead/bring something forward. A product is what corporations provide, whether it is a tangible item like a cell phone or a service like health care (Ahmed, 2015). In general, a product is a collection of goods and services that a corporation offers to its target market. Product diversity, quality, design, features, brand names, packaging, and services are all components of the product mix. Product strategy can have an impact on other marketing strategies. Buying a product is about more than simply having the thing; it is also about meeting the needs and wants of customers (Kotler, 2010).

It is recognized as a target market by broader society if the created product puts details on the demands and wants of its customer. Items developed must also have higher value, advantages, and benefits when compared to industry rivals. The design of Islamic banking products that based on contracts is originated from the muamalah principle (everything is permitted unless there is a prohibition in the Al-Quran and Hadith), allowing Islamic banks to produce a wide range of products and transform Islamic banks into Islamic financial institutions, rather than just banks (beyond bank).

Sharia banking products are derived from contracts based on the principles of buying and selling, profit sharing, and leases, which are then processed to produce derivative products such as Wadiah demand deposits, Wadiah or Mudharabah savings, Mudarabah deposits, Kafalah (collateral), Hawalah (factoring), Qard (bailout funds), Rahn (pawning), Sukuk (sharia bonds), Murabaha financing (buying and selling), Mudarabah (profit sharing and banks as investors), Musharakah (joint capital), Ijarah (leasing), Ijarah Muntahiya Bittamlik (lease-purchase), Istisna'a (purchases paid in 
stages), and Bai Salam (purchases paid in full in advance) (Indonesian Bankers Association, 2015).

In sharia marketing, product qualities must be realistic, humanistic, and transparent. Even the halal-ness of a sharia bank's product/service might be a distinguishing benefit over conventional products/services. As a result, Islamic banking products must fulfill product quality dimensions include the goods form, performance, features, reliability, conformance, durability, serviceability, aesthetics, and fit and finish. In the meantime, products in services must be reliable, responsive, assured, empathic, and tangible. Furthermore, the products created by Islamic banking are not in the form of goods but services. The features of the produced services must refer to Sharia values or those permitted by the Koran. However, to attract the interest of additional customers in the associated banking services, these products must continue to implement a "differentiation" or "diversification" strategy to entice them to switch and begin using sharia banking services.

\section{2) Price}

The price is the amount of money that customers must spend to obtain the goods (Kotler, 2010). In other meaning, the price is an exchange rate that can be equivalent to money or other items for the advantages acquired from a product or service at a specific time and location for a person or group. It is simply stated that the price is an indication of the selling value of the product or service that has been provided. Pricing is critical to pay attention to since it determines the behavior of banking products and services. Translating the meaning of pricing in Islamic banking may be analogized by examining how much sacrifice is made by customers to get a benefit in the form of services that are comparable with the sacrifices made by these consumers.

The price for banks based on sharia principles is profit-sharing (Kashmir, 2011). Aside from profit sharing, the cost for Islamic bank goods and services includes a margin, fee or service cost (Ujrah), and Ju'alah (success fee) for financing, fundraising, and providing services. Profit-sharing calculated in a ratio form (percentage of profitsharing between the bank and its customers) does not decide absolutely the amount of profit-sharing, but rather it is determined by the bank's performance. Customers of a 
ISLAMIC BANKING: Jurnal Pemikiran dan Pengembangan Perbankan Syariah, Volume 7 Nomor 2 EdisiFebruari 2022

bank with a higher ratio may receive a lower profit-sharing realization than bank's customers with a lower percentage ratio.

Costs may not be calculated as a proportion of the value of the financing. Financing debtors may be charged a collection fee under the bank's expenses. Islamic banks may levy penalties to ensure that the customers are disciplined for their obligations. Meanwhile, banks use the received funds for charitable purposes rather than to increase profit for the bank.

Islamic banks are not permitted to adjust margins or ratios unilaterally. Instead, they may provide discounted rates to financing customers with an excellent payment history or to seek to hasten repayment, but it may not be decided upon at the outset of the contract. Conventional banks will charge for early repayment bills of credit or withdrawal of deposits before the due date.

\section{3) Advertisement (Promotion)}

Promotion is an effort to offer the products to potential customers. In other words, promoting is a variety of activities undertaken by producers to explain the benefits of their products, persuade, and remind the targeted consumers to purchase them (Kotler, 2010). According to Buchari Alma and Hurriyati (2008), Promotion is a communication type of marketing. Marketing activity is that try to distribute information, influence/persuade, and remind the targeted market of the company and its products, for them to accept, buy, and be loyal to the items supplied by the company.

Promotion is the most powerful way to attract and retain customers. One of the bank's promotional objectives is to inform all the products offered and attract new potential customers. Banks frequently use print and audiovisual mass media to promote their products and services, for example, magazines, newspapers, and television. Advertising, sales promotion, publicity, and personal selling are among the promotional strategies that can be implemented.

The effectiveness of advertising is commonly used to develop a "brand image" or to make its presence recognized. When the "brand image" is embedded in the minds of the general public, selling a product, whether in the form of goods or services, will become 
easier. Promotion must be openly and ethically. All information, including product defects, must be provided to customers, both visible and invisible, and must not make false statements, exaggerate, and cover-up because all of these are inappropriate behavior and are strictly prohibited in the marketing and sales process. Islamic banks are very effective if they carry out propaganda through intensive and programmed $d a^{\prime} w a h$ and marketing public relations through testimonials on the advantages of results, buying and selling, free of negative spreads, and empowering certain ethnic groups or groups after being equipped with knowledge about Islamic banks to penetrate the market among them.

\section{4) Distribution (Place)}

The place of the marketing mix is usually called the distribution channel, the channel where the product reaches the consumer. For this reason, it is necessary to look for a place of business that allows taking profit; for example, strategic, easy to access, can be seen by many people, and has many promotions. Location or distribution is one of the keys to success in an effective marketing strategy. A strategic location that is easily accessible by customers is the basic principles of Islam about the obligation of the Caliph of Allah to manage existing resources in the best possible way. The bank will achieve the goal by determining the right location, for example, offices, ATMs, and human resources at crowded points, offices, or industrial areas. With proper distribution, banks can reach the community more optimally. The context that is easily accessible is not only in a physical sense but also in terms of convenience, ease of obtaining information, and the existence of safe transportation facilities in delivering goods or vice versa to the customer's place (Huda, et.al. 2017). A harmonious interior design, easy-to-see, organized, neatly put products, and so on are also features of the location (Rivai, 2012). In this instance, establishing Islamic banking service units in rural areas is essential if banks effectively enter the market. It demands the amount of capital if it has to be accomplished concurrently or simultaneously. 
ISLAMIC BANKING: Jurnal Pemikiran dan Pengembangan Perbankan Syariah, Volume 7 Nomor 2 EdisiFebruari 2022

\section{5) Marketers (People)}

People are an essential component of the marketing mix. People are all human beings who contribute to services that might impact consumer perceptions: corporate workers, customers, and other customers in the service environment are examples of people (Zeithaml et al., 2013). People are corporate employees, customers, and other customers in the service environment. Customers frequently appraise the services they receive based on their perceptions of the individuals who supply them. In marketing, the seller must give all relevant information about a product or service to make an informed decision for buyers. In reality, access to such information is a customer's entitlement under Islamic law (Chan et al., 2017).

We can interpret people as Human Resources (HR) of Islamic banking, either directly or indirectly, that might interact with clients (customers), and HR itself will highly correlate to the level of satisfaction of Islamic banking customers. One of them is a person actively involved in services and can impact customer perceptions. As a result, face-to-face services must have attractive and friendly workers and TASK capacity (Talent, Attitude, Skill, and Knowledge). Every employee of a sharia bank must have a motivation to participate in worship in the framework of preaching, learn banking operations, comprehend sharia principles as business basics, and have a service attitude (Aravik \& Hamzani, 2021).

\section{6) Process}

A process is an activity that demonstrates how services are provided to consumers during the purchase of products. The process refers to how the product will arrive in the final user, which is critical to customer satisfaction. Waiting time, the information offered to clients, employee awareness, speed in service offering, and employee contact in the proper manner are all critical factors in keeping customers pleased. Consumers are uninterested in the specifics of how a corporation is run because they want to know if the work system is functioning well (Chan et al., 2017).

How should the process or mechanism, from product offers to the procedure of managing client complaints, be established and improved? This process will be essential 
for the growth of Islamic banking, allowing it to generate products in the form of services that procedures can run effectively and efficiently while also being well appreciated by Islamic banking consumers. As a result, every service provided by units and persons must adhere to predefined service level requirements.

\section{7) Physical Proof (Physical Evidence)}

Physical evidence includes the setting in which the companies offer services and places where they interact with customers and physical components to promote performance and seamless service (Zeithaml et al., 2013). Organizations must utilize physical evidence as one of the aspects to create comfort, sense of peace and produce good job outcomes to increase organizational performance. Exterior design, signs (symbols, instructions, and directions), parking, vistas, and the surrounding environment, internal facilities, and other tangible assets are all examples of physical evidence (Abuznaid, 2012).

The method and form of service provided to Sharia banking customers is also tangible evidence that should be felt or considered as actual evidence for its customers, which one day it might bring a positive testimonial to the general public to support the acceleration of Sharia banking development in a better direction than it is now. As a result, the physical conditions of each contract point must be excellent, attractive, comfortable, and secure so that customers or visitors feel at home (like home), with the help of decoration, lighting system, room layout, room scent, and room comfort.

\section{Conclusion}

Based on the explanation above and the concerns discussed, it is possible to infer that ethics is an essential component in life, including in the Islamic bank marketing field, to support the performance of Islamic banks, particularly in the case of interacting with stakeholders. Advertising can utilize Islamic bank marketing ethics, like speaking a polite language. Marketing is implemented in polite words, professional acts, fair manner, including those from other religions, and transparent. In addition, it must put customers as equal as partners. Moreover, competitors are not parties to be defeated but can collaborate in realizing economic applications and sharia banking, as well as a work culture created in Islamic banking marketing that is distinct from conventional 
ISLAMIC BANKING: Jurnal Pemikiran dan Pengembangan Perbankan Syariah, Volume 7 Nomor 2 EdisiFebruari 2022

institutions. Prophet SAW's characteristics, including shiddiq (honesty), fathanah (competence or intelligence), Amanah (responsibility), and tabligh (ability to disseminate), direct the work culture. The marketing mix can apply this ethic to ensure that the source of peace is rooted and that justice is created in society, hence increasing dignity and upholding human rights. Islamic banks can execute marketing functions ethically by adopting Islamic marketing principles, ensuring that parties involved in the marketing process do not become victims of marketing manipulation, as is frequently the case in conventional marketing systems. 


\section{REFERENCES}

Abbas, A., Nisar, Q. A., Mahmood, M. A. H., Chenini, A., \& Zubair, A. (2019). The role of Islamic marketing ethics towards customer satisfaction. Journal of Islamic Marketing, 11(4), 1001-1018. https://doi.org/10.1108/JIMA-11-2017-0123

Abuznaid, S. (2012). Islamic Marketing: Addressing the Muslim Market. An - Najah Univ. J. Res. (Humanities)., 26(6), 1473-1503.

Ahmed, S. (2015). the Effects of Marketing Mix on Consumer Satisfaction: a Literature Review From Islamic Perspectives. Turkish Journal of Islamic Economics, 2(1), 17-17. https://doi.org/10.15238/tujise.2015.2.1.17-30

Al-Arif, N. R. (2012). Dasar-Dasar Pemasaran Bank Syariah. Bandung: Alfabeta.

Al-Nashmi, M. M., \& Almamary, A. A. (2017). The relationship between Islamic marketing ethics and brand credibility: A case of pharmaceutical industry in Yemen. Journal of Islamic Marketing, 8(2), 261-288. https://doi.org/10.1108/JIMA-03-2015-0024

Alma, B., \& Hurriyati, R. (2008). Manajemen Corporate Strategi Pemasaran Jasa Pendidikan. Bandung: Alfabeta.

Antonio, M. S. (2013a). Shiddiq: Personal Excellence. Jakarta: Tazkia Publishing.

Antonio, M. S. (2013b). Tabligh: Visionary \& Communicative Leadership. Jakarta: Tazkia Publishing.

Aravik, H., \& Hamzani, A. I. (2021). Etika Perbankan Syariah: Teori dan Implementasi. Deepublish.

Aravik, H., Sulastyawati, D., \& Yunus, N. R. (2020). Leadership Concept At Sharia Bank; Islamic Banking: Jurnal Penelitian Dan Pengembangan Perbankan Syariah, 5(2), 21-32.

Arifin, J. (2009). Etika Bisnis Islami. Semarang: Walisongo Press.

Basrowi, B., \& Ronaldo, R. (2019). Analysis of Sharia Marketing Constraints in Indonesia. Share: Jurnal Ekonomi Dan Keuangan Islam, 8(2), 207-237. https://doi.org/10.22373/share.v8i2.5365

Chan, A., Purbasari, R., \& Tresna, P. W. (2017). Sharia Marketing Analysis In Noor Hotel Bandung. Parahyangan International 3rd Accounting \& Business Conference, 560-576.

Dawwah, A. M. (2008). Meneladani Keunggulan Bisnis Rasulullah. Semarang: Pustaka Nuun.

Fauzia, N. I. (2014). Etika Bisnis dalam Islam. Jakarta: Kencana Prenada Media Group.

Firdaus, M. (2005). Dasar \& Strategi Pemasaran Syariah. Jakarta: Renaisan.

Hendarsyah, D. (2020). Pemasaran Digital Dalam Kewirausahaan. IQTISHADUNA: 
ISLAMIC BANKING: Jurnal Pemikiran dan Pengembangan Perbankan Syariah, Volume 7 Nomor 2 EdisiFebruari 2022

Jurnal Ilmiah Kkonomi Kita, 9(1), 25-43. https://doi.org/10.46367/iqtishaduna.v9i1.209

Hermawan, A. (2012). Komunikasi Pemasaran. Jakarta: Erlangga.

Iswandi, A. (2014). Peran Etika Qur'Ani Terhadap Sistem Ekonomi Islam. Al-Iqtishad: Journal of Islamic Economics, 6(1), 143-154. https://doi.org/10.15408/ijies.v6i1.1528

Jusmaliani. (2008). Bisnis Berbasis Syariah. Jakarta: Bumi Aksara.

Kotler, P. (2010). Manajemen Pemasaran. Jakarta: Erlangga.

Mujahidin, A. (2014). Ekonomi Islam; Sejarah, Konsep, Instrumen, Negara dan Pasar. PT. Raja Grafindo Persada.

Musoli. (2017). Etika Dalam Perspektif Manajemen Sumber Daya Manusia”, Bunga Rampai Manajemen Sumber Daya Manusia \& Perilaku Organisasional. Yogyakarta: Program.

Rozalinda. (2016). Ekonomi Islam. Raja Grafindo Persada.

Safitri, S., Suharyono, \& Arifin, Z. (2016). Shariah Marketing Characteristics and Trust: Study on Costumer BMT In Malang, Indonesia. RJOAS, 12(December), 74-78. https://doi.org/https://doi.org/10.18551/rjoas.2016-12.09

Shamsudin, A. S., Mohd Kassim, A. W., Hassan, M. G., \& Johari, N. A. (2010). Preliminary insights on the effect of Islamic Work Ethic on relationship marketing and customer satisfaction. The Journal of Human Resource and Adult Learning, 6(June 2010), 106-114.

Shinta, A. (2011). Manajemen Pemasaran. Malang: Brawijaya Press.

Swastha, B., \& Irawan. (2015). Manajemen Pemasaran Modern. Yogyakarta: Liberty.

Syauqi, M., Tri Ratnasari, R., \& Herianingrum, S. (2019). The Effects of Islamic Marketing Mix on Consumer Satisfaction and Consumer Loyalty. Icps, 192-200. https://doi.org/10.5220/0007540001920200

Tabrani, M., \& Marlizar, M. (2017). The Marketing Concept in Islamic Perspective: A Literature Review. AFEBI Islamic Finance and Economic Review, 1(01), 20. https://doi.org/10.47312/aifer.v1i01.19

Toriquddin, M. (2015). Etika Pemasaran Perspektifal-Qur'an dan Relevansinya Dalam Perbankan Syari'ah. De Jure, Jurnal Syariah Dan Hukum, 7(2), 116-125. http://ejournal.uin-malang.ac.id/index.php/syariah/article/view/3518

Yesil, S., \& . O. D. (2012). An Investigation into the Implications of Islamic Work Ethic (IWE) in the Workplace. Journal of Economics and Behavioral Studies, 4(11), 612-624. https://doi.org/10.22610/jebs.v4i11.362 
282 Havis Aravik, et.al, THE MARKETING ETHICS OF ISLAMIC BANKS: A THEORETICAL STUDY

Zarrad, H., \& Debabi, M. (2015). Islamic Marketing Ethics: A Literature Review. International Journal of Management Research \& Review, 5(2), 60-66.

Zeithaml, V. A., Bitner, M. J., \& Gremler, D. D. (2013). Services Marketing: Integrating Customer Focus Across the Firm 6thed. Mc.Graw-Hill. Boston. 